Ambiente \& Água - An Interdisciplinary Journal of Applied Science
ISSN 1980-993X - doi:10.4136/1980-993X
www.ambi-agua.net
E-mail: ambi-agua@agro.unitau.br

\title{
Editorial of the twenty third edition of Ambiente \& Água Journal
}

\author{
doi:10.4136/ambi-agua.1258 \\ Getulio Teixeira Batista \\ Universidade de Taubaté, SP, Brazil \\ Graduate Program in Environmental Sciences \\ Editor-in-Chief of Ambi-Agua Journal \\ e-mail: ambi-agua@agro.unitau.br
}

\begin{abstract}
The year 2013 marks a turning point in the journal's trajectory. This year, the "Open Access Year", is a year to remember for our journal. At the beginning of the year, we were chosen to be included in the SCOPUS Collection. In July, we were admitted to the Scientific Electronic Library Online (SciELO). In August, the US National Agricultural Library (NAL) invited Revista Ambiente \& Agua to be catalogued in the AGRICOLA database. We also were ranked in the B1 stratum of the Interdisciplinary Area by the "Qualis CAPES", the most important journal index in Brazil. By year's end, the Bid MCTI / CNPq / MEC / CAPES N ${ }^{\circ}$ 44/2013 had awarded us a grant aimed at encouraging the editing and publication of highly specialized Brazilian scientific journals in all areas of knowledge in order to significantly advance the country's scientific and technological development and innovation. We also participated in two major publishing events: SciELO 15 Years and The XIV ENEC (Brazilian National Conference of Science Editors). As with recent editions, this issue includes 20 peerreviewed articles. We continue our policies of complete open access and of working to increase the visibility of articles.
\end{abstract}

Keywords: Ambiagua, environment, water resources, Qualis CAPES, SciELO.

\section{Editorial da vigésima terceira edição da revista Ambiente \& Água}

\section{RESUMO}

O ano 2013 marca um ponto de inflexão na trajetória da Revista Ambiente \& Água. Neste ano de 2013, o "Ano do Acesso Aberto", não é para ser esquecido pela Ambi-Agua. No início do ano, a revista foi aceita para integrar a Coleção SCOPUS. Em Julho, foi admitida na Scientific Electronic Library Online (SciELO). Em agosto, a Biblioteca Nacional de Agricultura dos EUA (NAL) convidou Revista Ambiente \& Água para integrar o banco de dados AGRICOLA. A revista também foi classificada no estrato B1 na Área Interdisciplinar do indexador de revistas mais importante do Brasil o "Qualis CAPES". Antes do final do ano, a Ambi-Agua foi contemplada na Chamada MCTI / CNPq / MEC / CAPES N ${ }^{\circ}$ 44/ 2013, que teve como objetivo selecionar propostas para apoio financeiro para incentivar a editoração e publicação de periódicos científicos brasileiros de alta especialização em todas as áreas de conhecimento de forma a contribuir significativamente para o desenvolvimento científico e tecnológico e inovação do País. Participamos de dois importantes eventos de divulgação científica: SciELO 15 Anos e o XIV ENEC (Encontro Nacional de Editores Científicos). Como as recentes edições, esta edição inclui 20 artigos revisados por pares. Continuamos nossa política de acesso aberto completo e empenhados em aumentar a visibilidade dos artigos.

Palavras-chave: Ambiagua, ciências ambientais, recursos hídricos, Qualis CAPES, SciELO. 


\section{DISCUSSION}

Both the SciELO 15 Years and XIV ENEC conferences underscored the fact that the Open Access (OA) publishing model had reached a point of no return. The concept is ample and covers a large spectrum of access licenses for scientific articles and data. The benefits of this system have been discussed worldwide, as, for example, at the Open Access Week 2013 (http://www.openaccessweek.org/). The most important aspect of the OA initiative is the high visibility and the increased chance of citation that the articles afford. However, the costs of Open Access remain an issue. It is challenging to go from a journal subscription model or pay-per-article access to completely free and open access to articles. In this model, the author's institution or the author himself must pay publishing expenses or the journal must be sponsored by an institution, a member society or a research funding agency. However, the costs of publication must be covered in order to make the publication available free of charge. Funds from governmental research support agencies to directly support journals are quite limited. The trend is to support the researchers and have the researchers use part of their budget to cover the expense of publication.

The Ambiente \& Água Journal has practiced the OA policy since its inception and is completely committed to this policy. However, as the journal has increased in recognition, it has begun to receive a large number of submissions that require an expert team to handle the editorial process with timeliness and accuracy. As a result of the growing impact of the journal, it was selected to receive a grant from CNPq/CAPES under the public bid $n{ }^{\circ} 44 /$ 2013 funds meant to encourage editing and publication. It should be noted, however, that these funds cover less than $20 \%$ of the journal's publication costs, even though the journal was ranked $37^{\text {th }}$ out of 188 selected journals in a very competitive bid. But the important point is the fact of the journal's selection, considering that the judgment criteria included: Qualification of the Proponent / Editor and Scope of the Editorial Board; Qualis and Indexing in Databases; Scope of the Publication (National / International); Uniqueness of the Journal; Consistency of Editorial Policy and Punctuality and Efficiency of Publication of Articles.

Other points that were emphasized in the SciELO and ABEC meetings were the need for journals to be internationalized, professional and interoperable. To be internationalized, there is a clear need to increase publication in English, the language of science, and to select world class papers that promote the advancement of science. Professionalism implies having a competent and efficient editorial team working with a competent Editorial Committee. To increase interoperability, the articles and their metadata must be in the XML format in the initial phase of editing and must use flexible platforms capable of interacting with search engines to allow for interfacing with social media in order to take advantage of the new alternative metrics which are growing in popularity, such as "altmetrics", for example (http://altmetrics.org/about/).

Considering the requirements to remain in SCOPUS and in the prestigious SciELO Brazil Collection, and further considering the trend towards high-standard scientific journals, Revista Ambiente \& Água will pursue several procedural changes. We have already changed the layout of articles. Next year, we will change page numbering and increase the geographic and thematic scope of our Scientific Committee, which already includes several new international members that are committed to the journal and whose selections will be announced early next year. The Editorial Board is therefore exploring possible means to adequately finance a professional editing system. 